\title{
Implementation of Mathematics Learning Through Media Arrange Smart Dice to Improve Counting Ability in Early Childhood
}

\author{
Yelva Nofriyanti ${ }^{1}$ \\ Heni Meila Sari ${ }^{2}$ \\ Universitas Negeri Padang
}

DOI: https://doi.org/10.21009/10.21009/JPUD.131.12

Accepted: $15^{\text {th }}$ March 2019. Published: $30^{\text {th }}$ April 2019

\begin{abstract}
The implementation of mathematics learning in some kindergartens in the city of Padang has not developed optimally. While in Rahmah Abadi Kindergarten that learning mathematics, especially numeracy has been well developed. The purpose of this study was to describe the implementation of mathematical learning using smart dice media for children's numeracy in Rahmah Abadi Kindergarten. The research method used was descriptive approach qualitative. Data collection techniques used are observation, interviews, and documentation. The results showed that the implementation of mathematics learning using smart dice stacking media in kindergarten Rahmah Abadi was a child who was able to recognize numbers, count numbers 1-10 and simple summation.
\end{abstract}

Keywords: Media Arrange Smart Dice, Counting Ability

(C) 2019 Early Childhood Education Post Graduate Program UNJ, Jakarta e-ISSN (Online Media): 2503-0566

P-ISSN (Print Media): 1693-1602

\footnotetext{
${ }^{1}$ Corresponding Author:

Yelva Nofriyanti

Early Ehildhood Education Programs, Universitas Negeri Padang

J1. Prof. Dr. Hamka, Air Tawar Barat, Padang

Email: yelvanofriyanti151195@gmail.com
} 


\section{INTRODUCTION}

Education is a very important requirement for humans because education plays an important role in improving human resources and needs to be given since an early age. One of the educations proposed to develop the potential of children from an early age is early childhood education. The purpose of learning in kindergarten is to improve children's creativity and encourage them to get to know various kinds of knowledge. In kindergarten there are several aspects that need to be developed, namely aspects of the development of religious and moral values, aspects of cognitive development, aspects of motoric physical development, aspects of language development and aspects of social emotional development.

Every aspect of child development supports each other. One aspect of its development is the aspect of cognitive development. Cognitive abilities consist of general knowledge and science, concepts of form, color, size, pattern and mathematics. One aspect of cognitive development is mathematics learning. Learning mathematics for early childhood is designed so that children are able to master the mathematical skills needed in everyday life. Mathematics is a part of cognitive that is very important for the development of children's intelligence. According to Triharso (2013, p. 46), Mathematics is something that is related to abstract ideas / concepts arranged hierarchically through deductive reasoning.

One of the activities to improve the ability to count children through dice that is done by the teacher in class is by playing dice alternately. The game is done by throwing the dice, then the child is told to count the number of symbols on the dice, then the child is asked to show numbers and write them on the board write. But when the game takes place, there are many children who pay less attention to the activities that take place, some children are only joking and busy with their respective activities. This is due to the small size of the dice so that when the child counts the number of points on the dice it is not visible to other friends. In addition, the activities carried out look boring for children.

Dice games are activities that will be applied to improve children's numeracy skills. Dice is a small object in the shape of a cube and is used to produce numbers or random symbols (E Sovia, 2015). Dice is often used in children's games and is generally used in pairs. During this time the dice that are commonly used are small cuboid objects that are used to produce numbers. Usually on each side of the dice there are symbols in the form of numbers or are marked in such a way that when the dice is thrown on a flat plane, one side will show a certain number. The small size of the dice and the symbols in the dice cause a lack of attractiveness in calculating the child, but if the dice are made in large sizes, and the point symbol is replaced with different images and the learning method accompanied by music will increase interest children in learning using media dice.

Therefore, the author tries to modify the dice into dice that can develop children's numeracy skills. The researcher modifies a media that can improve children's numerical abilities in the form of Arranging Smart Dice so that children are easy to recognize the concept of numbers with objects. Media Arrangement Smart dice consists of many parts, namely a dice, a picture card, and small dice arranged on a pole. The way to use this media is when the teacher turns on the music, the dice are given by the child to a friend next to him. When the music is stopped, the last child holding the dice will throw the dice, and the child is asked to count the symbols on the dice. After that, the child is asked to take a picture in the box. Next the child will count how many pictures are on the card. Then the child takes a small dice and arranges it on the pole according to the 
number of objects in the picture. The child matches the number of images on the card by taking the dice according to the number on the card, then the child arranges a small dice on the pole.

Based on the results of interviews of researchers with teachers in the Lubuk Begalung Kindergarten in Padang, it was found that there were 12 children in class B1 where understanding the concept of counting children was still lacking, such as numbering numbers, recognizing the concept of numbers with objects, connecting or pairing numbers with objects. Children have not been able to connect between concepts with symbol numbers, children are also often reversed in the mention and writing of numerical names, children can only mention the concept of numbers without knowing the symbol of the number.

According to the analysis, the author needs a learning media for teachers and children to carry out the learning process at school in improving children's numeracy skills. Based on that, the author develops learning media that are herded in the process of learning activities. The author gave the title of this research with "Implementation of Mathematics Learning Through Media Arranging Smart Dice on the Ability of Counting Children in Kindergarten Rahmah Abadi Lubuk Begalung Padang".

\section{Early Childhood Education Concept}

Early age is the most important time in the life span of a child. Currently the growth of the brain is experiencing very rapid development, as well as its physical development. Early childhood is a figure of an individual who is undergoing a process of rapid development and fundamental to the next life (Sujiono, 2008, p. 6). Early childhood is in the age range of 0-8 years. The process of growth and development in various aspects is experiencing a rapid period in the development range of human life.

According to Suryana $(2013$, p. 25) states that early childhood is the most important and fundamental initial period throughout the span of growth and development of human life. At this time, it was marked by various fundamental important periods in the lives of the next child until the end of their development period. Early childhood is a person who has a very "unique" character (Mulyani, 2016, p. 19). The uniqueness of the character makes adults feel anxious, amazed and entertained if they see their funny and laughing behavior. No fewer parents make their children entertainment, after undergoing a very dense and tiring routine.

The characteristics of early childhood are unique, egocentric, active and energetic, feeling strong and enthusiastic about many things, explorative and adventurous, spontaneous, happy, and rich in fantasy, still easily frustrated, still not consider and do something, short attention, passionate to learn and learn a lot from experience and increasingly show interest in friends (Sudarna, 2014, pp. 16-17). The characteristics of early childhood are to think concretely, realism, egocentricity, a tendency to think simply and not easily accept something that is plural, animistic, sentimental, and early childhood can be said to have imagination very rich (Mashar, 2011, pp. 14-15) .

Early Childhood Education is an effort aimed at children from birth to the age of six through the provision of educational stimuli so that children grow and develop well so that they can carry out each developmental task in accordance with the stages of development. Early childhood education is a coaching effort aimed at children from birth to the age of six years which is carried out through the provision of educational stimuli to help growth and physical and spiritual development so that children have readiness in entering further education (Trianto, 2011, p. 24). The goal of early childhood education is to provide stimulation or stimulation for the development of children's potential to become human believers and fear the Almighty God, noble, healthy, knowledgeable, 
capable, critical, creative, innovative, independent, confident, and a democratic and responsible citizen (Ulfah., 2013, pp. 19-20). The purpose of early childhood education is to develop knowledge and understanding of know-how and teachers, as well as those related to education and development in early childhood (Susanto, 2017, p. 23).

\section{Mathematics in Early Childhood Learning Activities}

One aspect of cognitive development is learning mathematics. Learning mathematics for early childhood is designed so that children can master the mathematical skills needed in everyday life. Mathematics is a part of cognitive that is very important for the development of children's intelligence. Mathematics is something related to ideas / abstract concepts that are arranged hierarchically through deductive reasoning (Triharso, 2013). Mathematics in PAUD is an activity to learn about mathematical concepts through playing activities in daily life and is scientific in nature. The mathematical concept for early childhood is divided into several concepts that are appropriate for the development of children aged din as follows:

1. Are the items the same or different? different items are easier to match.

a. easier

b. harder

2. Are there many items that are suitable or only a few?

a. Easier (five or fewer items)

b. More difficult (more than five items)

3. Are there the same numbers in each set?

a. Easier (even set)

b. More difficult (not enough, or too much in one set)

4. Does the set "join or not join?

a. Joining is easier

b. Not joining is more difficult (Smith, 2009)

Mathematics is an important part of learning for all children in the early years and good basic preparation in the field of mathematics is an important life skill. As well as counting, this helps skills such as solving problems, solving and using forms and measuring and developing their own spatial awareness. This helps them to correct, make and evaluate patterns, which are important for early problem-solving. Introducing mathematics to children from an early age helps develop their understanding of all elements of problem solving and punishment in various contexts. Practitioners need to provide opportunities for children to develop their skills and knowledge to improve their competence and confidence in using.

Math and Play words are not available at all. For many of us, mathematics is tormenting, something we must do, and something we cannot understand and cannot do. Playing on the other side is something we like. Young children learn mathematics all the time through a variety of playing experiences. Since they argue, babies are approved by sensory impressions. The special form is very important: the baby has just finished the arrangement of the shape of the human face. At home, in groups of parents and toddlers, and children, children have many opportunities to enjoy and learn Mathematics through Play. "Playing is an effective vehicle for developing mathematical concepts and developing positive attitudes towards mathematics ... Adults in pre-school environments must be sponsored by informal mathematical experiences that children have acquired in their home environment."

Mathematics is all about solving and using shapes, space, size, and numbers to solve everyday problems such as how much masking tape is used to wrap parcels or the number of red balloons that need to be bought enough for all holiday party children. Helping children enjoy Mathematics 
may be one of the most important things adults can do so children understand mathematical ways to find things and solve problems. When something has meaning, for children, they will learn it even children choosing two years will ask for number 2 after seeing and talking about their birthday cards. Children often say 'that's my number' they compile see numbers two, three, four or five - because their age (they mean) is special to them. Likewise, the compilation of children acknowledged that they had the same number of raisins as other children, they began to apply their knowledge of equality.

The basic concepts of mathematics and numbers in early childhood education emphasize the basis for learning mathematical concepts as the initial foundation. Mathematics is given and several activities provide more comfort to children so that children can master mathematics by enjoying it. In addition, with comfort in the process of introducing mathematics, it can train and increase children's self-confidence. Children who learn comfortably math concepts and numbers and will make them believe that he is "good at math." If a child is not familiar with mathematical concepts and numbers at an early age, he will lack confidence in his abilities and may become doubtful when mathematical concepts which is more difficult later. When this happens, he may fail to believe that he is "not good in mathematics" and will automatically risk be starting failure by itself.

Children are using early math skills throughout their daily routines and activities. This is good news as these skills are important for being ready for school. But early math doesn't mean taking out the calculator during playtime. Even before they start school, most children develop an understanding of the addition and subtraction through everyday interactions. For example, Thomas has two cars; Joseph wants one. After Thomas shares one, he sees that he has one car left (Bowman, Donovan, \& Burns, 2001, p. 201). Other types of introduced routines through daily routines you share with your child - you go up or down, for example. Informal activities like this one give children a jump on the formal math instruction that starts in school.

Early mathematical concepts and skills for the first-grade curriculum build on include:

- Understanding size, shape, and patterns

- Ability to count verbally (first forward, then backward)

- Recognizing numerals

- Identifying more and less of a quantity

- Understanding one-to-one correspondence (i.e., matching sets, or knowing which group has four and which has five) (Bowman et al., 2001)

\section{Calculate}

One ability that is very important for children that needs to be developed in equipping the lives of children in the future and now is to provide provision for numeracy skills. Counting is not only related to cognitive abilities, but also mental, social and emotional readiness. Therefore, in implementing learning to count, it must be done in an interesting, varied and fun way.

Counting is a way of learning about the name of the number to identify the number of objects in accordance with the ability of reason in summing them up (Sujiono, 2008). Counting is a part of mathematics (Suryana, 2013). The ability to count is needed to develop children's knowledge about numbers, numbers, addition, and subtraction. In addition, counting is also the basis for the development of children's mathematical abilities to attend further education. 
Calculations are the ability to count to 100 is a generally accepted standard of assessment in many kindergarten schools, parents, principals, and some teachers use oral calculations in more advanced ways of thinking the following:

- Read numbers, for example, "This is' three".

- Writing numbers, visual-motor assignments

- Match numbers to a set, or the cardinality principle, for example, count 5 seeds and answer a question, "How much?

- Has an intuitive feel for how big the numbers are, for example, "Are 15 closers to 10 or 50 ?

- Able to make reasonable guesses using numbers, for example, "small bottles cannot hold more than 0-100 carp crackers."

- Look at the relationships of parts by using vision or abstract thinking (without counting), " (Smith, 2009)

There are four step counting in early childhood, pre-counting, one-to-one counting, and counting from one to solve number problems (Newzealand, 2013). Pre-counting is an understanding of the concepts more, less and the same and an appreciation of how these are related. Children at this stage develop these concepts by comparison and no counting is involved. This is important because these concepts lay the foundation for children to later develop an understanding of the many ways that numbers are related to each other; for example, five is two more than three, and one less than six. Children often have some concept of more; this needs to be extended and refined. Less is a more difficult concept and understanding can be developed by pairing the terms less and more to help develop an understanding of the relationship between the two (Newzealand, 2013).

One-to-one counting is developing children's ability to count. Two skills are needed: $\bullet$ the ability to say the standard list of counting words in order $\bullet$ the ability to match each spoken number with one and only one object. Counting is important because the meaning attached to counting is the key conceptual idea on which all other number concepts are based. Children have often learned the counting sequence as a rote procedure. They need to learn the meaning of counting by using counting skills in a variety of meaningful situations. Start with counting small numbers, up to five objects. Once children can count reliably their knowledge of the number sequence can be extended to count both forwards and backward, from any given number (Newzealand, 2013).

The counting sets are developing children's understanding of cardinality. This means that children understand when you count the items in a set, the last number counted tells the size of that set. They also know that the number in a set will remain constant if no items are added to the set or taken from the set. Cardinality is important because it allows numbers to be used to describe and compare sets. This allows sets of items to be combined (addition) and separated (subtraction). Children develop an understanding of cardinality by counting a variety of objects into different sized sets. Counting the same set several times and in a different order develops children's understanding that the number in a set stays the same unless items are added or taken away. The ability to recognize and write numerals are important skills to develop alongside counting (Newzealand, 2013).

Counting from one to solve number problems. The counting objects to solve addition and subtraction problems. Children will need to use materials such as buttons, plastic animals, or whatever they may be playing with, to keep track of their counting. For example, children will combine 3 and 2 by first counting out " $1,2,3$ " for the first set, then " 1,2 " for the second set, then physically 
join the sets and counting them all "1,2,3,4,5." Once children understand cardinality and the forward and backward number sequences they can count on or back to solve number problems. For example, 5 and 3 can be added by counting on from the largest number: " $5 \ldots . . .6,7,8$ ". Using counting to solve number problems shows children that counting can be used meaningfully in a variety of situations. This helps them understand and appreciate counting as more than a rote procedure. Using counting to combine and separate groups of objects develop children's understanding of the operations of addition and subtraction. Children come to understand that when groups are combined the count gets bigger, and when groups are separated the count gets smaller. Encourage children to count a wide variety of concrete materials to solve number problems. Start by joining small sets, with a total of five and then ten items. Encourage children to count on to solve number problems by taking the focus away from counting the items in the first set. Use comments which encourage children to count on from the largest number (Newzealand, 2013).

The purpose of this study was to find out the implementation of learning mathematics through multimedia smart dice stacking for numeracy skills of children in Rahmah Abadi Kindergarten, Begalung Sub-district, Padang.

\section{METHODS}

This type of research is descriptive using a qualitative approach. Qualitative research is research that is based on the philosophy of postpositivism which is used to examine natural object conditions, where the researcher is a key instrument, the technique of data collection is triangulated (combined), data analysis is inductive / qualitative and the results of qualitative research emphasize the meaning rather than generalization (Sugiyono, 2016, p. 9). Descriptive research is data collection to provide an overview or affirmation of a concept or symptom as well as answering questions related to a research subject through surveys, questionnaires, interviews or observations (Darmadi, 2014, p. 5).

This research was conducted in the Rahmah Abadi Lubuk Begalung Kindergarten Park, Padang City, West Sumatra. The research instrument is a tool used to measure research variables. Research instrument is a tool or facility used by researchers in collecting data so that work is easier, and the results are better, in the sense of being meticulous, complete, and systematic so that it is easier processed. Instruments used to collect data in research, namely observation format, interview format, and documentation format (Arikunto, 2014, p. 203).

The data source of this study were research subjects and research informants. The subjects of this study were teachers and children in Rahmah Abadi Kindergarten and research informants were teachers and principals as leaders and policy makers in the Rahmah Abadi Kindergarten.

The validity technique of the data in this study is to use triangulation and use reference material. Triangulation in testing credibility is defined as checking data from various sources and various times (Sugiyono, 2016). Using reference materials, there are supporters to prove the data that has been found by the researcher. Data on the interview results need to be supported by the existence of interviews and documentation such as photographs.

\section{RESULT AND DISCUSSION}

Recapitulation of Post-Test Results Development of Counting Ability of Children in Experimental Classes using smart dice stacking media and control classes using numeric cards. 
Based on the research, the experimental class with 15 children had the highest score of 100 and the lowest value was 68.75 . From the value of the experimental class, children obtained an overall value of 1200 , median 78.87 with an average value of 80 standard deviations 7.9 and the variance value 63.52 .

While the control class with 15 children had the highest score of 87.5 and the lowest score was 62.5. From the value of this control class, the overall number is 1106.25 , median 73.5 with an average value of 73.75 standard deviations 6.92 and the variance value is 47.88 .

\subsection{Pre-test Data Analysis}

\subsubsection{Normality Test}

Based on the normality test of the experimental class and the control class, the prices of Lo and Lt were obtained at a real level of 0.05 for $\mathrm{N}=15$ as in the following table:

Table 1. Calculation Results of Liliefors Pre-test Test Experiments and Control Classes

\begin{tabular}{rlrrrrl}
\hline No & Group & $\mathrm{N}$ & $\mathrm{A}$ & $\mathrm{L}_{0}$ & $\mathrm{~L}_{\mathrm{t}}$ & Explanation \\
1 & Eksperimen & 15 & 0,05 & 0,13 & 0,220 & Normal \\
2 & Kontrol & 15 & 0,05 & 0,1943 & 0,220 & Normal \\
\hline
\end{tabular}

Thus, the value of the experimental class comes from data that is normally distributed. For the control class, Lcount 0.1943 is smaller than Ltable 0.220 to 0.05 . This means that the control class data comes from data that is normally distributed.

\section{Homogeneity Test}

The second requirement test is homogeneity testing using the Barlett test.

\section{Hypothesis Test}

Hypothesis testing uses t-test. From the results of hypothesis testing using the t-test the following results are obtained:

Table 2. Pre-test Calculation Results Test with t-test:

\begin{tabular}{rllllll}
\hline No & Group & $\mathrm{N}$ & Average & $\mathrm{t}_{\text {count }}$ & $\begin{array}{l}\mathrm{t}_{\text {tabel }} \\
\alpha 0,05\end{array}$ & Decision \\
& Experiment & 15 & 59,16 & & & \\
1 & Control & 15 & 57,91 & 0,448 & 2.04841 & AcceptedH $_{\mathrm{o}}$ \\
\hline
\end{tabular}

In the table $\mathrm{df}$ for the real level $\alpha=0.05(5 \%)$ the value of $\mathrm{t}$ table $=2.04841$ is obtained, so the $\mathrm{t}$ count is smaller than $\mathrm{t}$ table $(0.448<2.04841)$. Then it can be said that Ha hypotesis was rejected or Ho was accepted 


\subsection{Post-test Data Analysis}

\subsubsection{Normality Test}

Based on the normality test of the experimental class and the control class, the L0 and Lt prices were obtained at the 0.05 significance level for $\mathrm{N}=15$ as in the following table:

Table 3. Calculation Results of Liliefors Post-test for Experimental Classes and Control Classes

\begin{tabular}{rlrrcrl}
\hline No & Group & $\mathrm{N}$ & $\mathrm{A}$ & $\mathrm{L}_{0}$ & $\mathrm{~L}_{\mathrm{t}}$ & Explanation \\
& Experiment & 15 & 0,05 & 0,1924 & 0,220 & Normal \\
2 & Control & 15 & 0,05 & 0,1642 & 0,220 & Normal \\
\hline
\end{tabular}

Based on the table the experimental class value of $\mathrm{L}$ count 0.1924 is smaller than $\mathrm{L}$ table 0.220 for $\alpha=0.05$. Thus, the value of the experimental class comes from data that is normally distributed. For the control class, $L$ count 0.1642 is smaller than $L$ table 0.220 for $\alpha=0.05$. This means that the control class data comes from data that is normally distributed.

\section{Homogeneity Test}

If chi squared counts < chi squared table means data comes from a homogeneous group.

Table 4. Homogeneity Test Results of Experimental Classes and Control Classes

\begin{tabular}{llccc}
\hline Group & A & $\chi_{\text {value }}^{2}$ & $\chi_{\text {table }}^{2}$ & Conclusion \\
$\begin{array}{l}\text { Experiment } \\
\text { Control }\end{array}$ & 0,05 & 0,378 & 3,841 & Homogen \\
\hline
\end{tabular}

Based on the table the count of the experimental class and the control class is smaller than the table (value <table), meaning the experimental class and the control class have homogeneous variances.

\section{Hypothesis Test}

The following will be described processing data by t-test.

Table 5. Results of Experimental and Control Class Post-test Value Calculation

\begin{tabular}{ccc}
\hline Aspect & Experiment Class & Control Class \\
$\mathrm{N}$ & 15 & 15 \\
$\bar{X}$ & 80 & 73,75 \\
$\mathrm{SD}^{2}$ & 63,52 & 47,88 \\
\hline
\end{tabular}

Based on the table above with dk $(\mathrm{N} 1-1)+(\mathrm{N} 2-1)=28$. In the df table for the real level $\alpha 0.05$ the price is $t$ table2.04841, so $t_{\text {value }}$ is greater than $t_{t(\text { table) }}$.

After calculating the pre-test and post-test values of the experimental and control classes, a comparison will be made between the pre-test and post-test values. 
Table 6. Comparison of Results of Calculation of Pre-test Values and Post-test Values

\begin{tabular}{ccccc}
\hline \multirow{2}{*}{ Variabel } & \multicolumn{2}{c}{ Pre-test } & \multicolumn{2}{c}{ Post-test } \\
& Experiment & Control & Experiment & Control \\
Highest Score & 68,75 & 68,75 & 80 & 73,75 \\
Lowest Score & 43,75 & 37,5 & 68,75 & 62,5 \\
Average & 59,16 & 57,91 & 80 & 73,75 \\
\hline
\end{tabular}

So, it can be concluded that the development of the ability to count influential children with smart dice stacking media compared to numeric cards, can be seen from the value of the average achieved by the child, namely the experimental class 80 while the control 73.75 .

The findings obtained from observations, interviews and documentation that the researchers did about the ability of children to recognize the concept of numbers and counting, which is known that children's numeracy capacity has not developed, either when the child counts the numbers using fingers or props that support children's numeracy.

Based on the findings, interviews, and documentation regarding the implementation of learning through the media of smart dice stacking on numeracy skills, children look enthusiastic in using this media. This was seen when demonstrating the children's media was so excited. Media Arrange smart dice consists of many parts, namely a dice, picture cards, and small dice arranged on a pole. The implementation of this media is when the teacher turns on the music, the dice are given by the child to a friend next to him. When the music is stopped, the last child holding the dice will throw the dice, and the child is asked to count the symbols on the dice. After that, the child is asked to take a picture in the box. Next the child will count how many pictures are on the card. Then the child takes a small dice according to the picture of the object on the card. Furthermore, the number of objects is matched with the number of dice that the child has taken and arranged on the pole.

Counting with dice games makes children active and does not make children bored because children are directly involved in the game. Through dice, children's learning activities are more fun so that the child does not feel that he is learning. This is in line with the opinion of Appiquantum dice games can be done in various ways and can be used to teach various kinds of mathematical concepts such as recognizing numbers, addition, subtraction, counting, multiplication concepts, volume concepts (E Sovia, 2015).

Everyone from various ages likes games that are fun and motivating. The game gives students the opportunity to discuss the concepts of fundamental numbers, such as the sequence of calculations, one-to-one correspondence, and calculation strategies. Involving math games can also encourage students to explore numerical combinations, place values, patterns, and other important mathematical concepts. Furthermore, they provide opportunities for students to deepen their mathematical understanding and punishment. The teacher must provide different opportunities for students to play games, then let mathematical ideas emerge with students who pay attention to new patterns, relationships, and strategies (Rutherford, 2015). Games are important tools for learning in elementary school math classes:

- Playing games encourages thinking math strategies composing students find different strategies to solve problems and deepen their understanding of numbers.

- When played repeatedly, this game supports the development of students' computing abilities. 
- Games provide opportunities for practice, support without the need for teachers to provide challenges. The teacher can then issue or assess students and work with individuals or small groups of students.

- Games have the potential to enable students to develop familiarity with numerical systems and with "benchmark figures" (such as the 10s, 100s, and 1000s) and engage in computational practices, building a deeper understanding of operations.

- The game supports school relationships and parents. Parents can learn about learning their children's mathematics by playing games with them at home (Rutherford, 2015).

The findings of observations, interviews and documentation of the implementation of mathematics learning through smart dice stacking media that have been carried out have been well implemented seen in joint circular activities and direct practices applied by the students. Guidelines for implementing learning are usually practiced directly by classroom teachers and accompanying teachers in activity positions learn together in a circle so that it is easier for children to focus on learning.

Based on the findings and interviews about the children who took part in the learning process, it was done well, namely by direct practice carried out in the process of learning the child was able to use learning media without help from the teacher and not only that, when the child took turns using the media patiently waiting for the queue. But in terms of time, the implementation of learning does not work according to the proper procedures because there are many children and limited time so that not all children can turn in using the media.

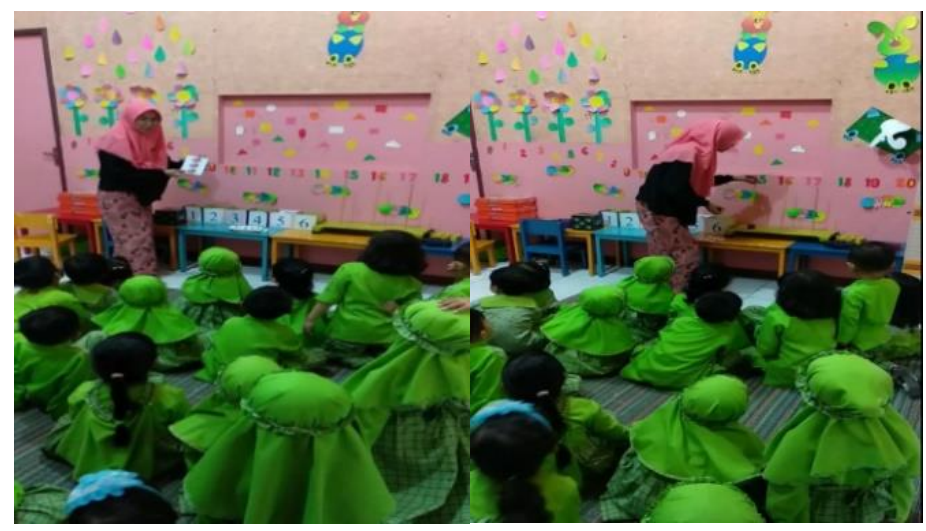

Figure 1. Researchers explain the procedures for using media

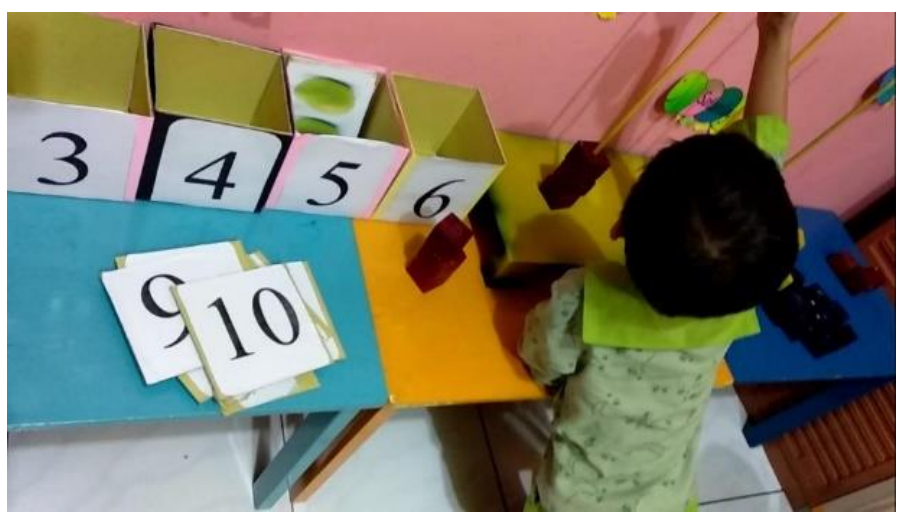

Figure 2. Children match the number of images on the card and match them to the number of dice, then arrange them on a pole 
The dice media can be used as a multifunctional media in the calculation game (Rohmah \& Waluyo, 2014). Media dice is used as a game media because playing is the need of every child. The principle of learning media is beneficial for help students learn to understand something which may be difficult or complicated or to be simplified something (Suyanto, 2003, p. 161).

Based on the results of the research during the learning activities, this media is very effective to use at school because it meets the requirements of a learning media. The type of media that is designed is a smart stacking media that can develop children's numeracy skills. This media is a medium that is durable and made at affordable prices because it is made using wood and paper and can be used by all parties whether at school or at home. In line with the opinion of Arsyad (2013) explained that the criteria for learning media are in accordance with the objectives, practical, flexible, enduring, capable and skilled in using and grouping targets (Arsyad, 2013).

Based on the trials that have been conducted, there are several advantages and disadvantages. The advantages of smart dice stacking media are as follows: 1). Smart dice stacking media attracts the attention of children because the learning media uses dice that are illustrated and accompanied by music. 2). The child feels challenged when trying out the media to arrange smart dice so that the child is optimistic about counting. 3). Smart dice stacking media can train children to recognize the concept of color

Besides having the advantages of smart dice stacking media, it also has disadvantages, namely in making smart dice stacking media, it is easy, but it requires expertise and knowledge in making it.

Smart dice stacking media as one of the medias in teaching and learning activities is very useful in developing children's numeracy skills. This media consists of various features including, picture and number cards and small dice arranged on a pole. So that through the card the child can count the number of objects and be able to mention numbers. Numeracy is the basis of developing mathematical abilities that must be developed early (Oktriyani, 2017, p. 83).

One of the development activities of counting is one of the children calculates the number of objects using smart dice stacking media. The use of smart dice stacking media can make it easier for children to take part in learning activities and foster children's interest, this is because the use of smart dice stacking media can be alternated and accompanied by children's songs. In line with what was stated Arsyad (2013) that the use of learning media in the learning process can increase new desires and interests and bring influence to children.

Learning media can facilitate the learning process because learning will attract children's attention so that it can foster children's learning motivation and learning methods will be more varied. Kustandi (2013, p. 25) suggest the benefits of learning media in student learning processes, namely as follows: 1) Learning will become more attractive to students' attention, 2) Learning materials will be more meaningful, 3) Methods learning will be more varied.

Naturally, children always want to know everything. They explore concepts when interacting with their environment for example, start learning math concepts as they play and build towers using beams. When children build blocks, they sort beams based on size and color, spatial and develop reasoning skills (Harris \& Petersen, 2017). Reasoning skills is meant when determining which form can be placed on top or forming a certain object according to their wishes, for example forming a plane or robot. 
Preschoolers count or compare the objects they play and learn patterns and shapes. Children must interact with adults to learn the mathematical concepts they drive. Parents and teachers can provide mathematical concepts into their daily routines. For example, while building towers or reading books, parents can show and use different sizes and shapes. Daily routines and done while playing will be easier to teach mathematical concepts in pre-school children, including the concept of counting. The ability to count in early childhood can be developed with fun games.

\section{CONCLUSION}

The results of this study describe the implementation of mathematics learning through a medium of smart dice stacking on the numeracy ability of children in kindergarten Rahmah Abadi Lubuk Begalung Padang has been well implemented as seen in the joint circular activities and the direct practices applied by the group. Guiding the implementation of learning in the form of practice is directly carried out by the classroom teacher and the accompanying teacher in the activity position to learn together in a circle so that it is easier for the child to be focused in following the learning.

\section{REFERENCES}

Arikunto, S. (2014). Prosedur Penelitian. Jakarta: Rineka Cipta.

Azhar Arsyad. (2013). Media Pembelajaran. Jakarta: Rajawali.

Bowman, B. T., Donovan, M. S., \& Burns, M. S. (2001). Eager to Learn. Eager to Learn. Washington DC: NAtional Academy Press. https://doi.org/10.17226/9745

Darmadi, H. (2014). Metode Penelitian Pendidikan Sosial. Bandung: Alfabeta.

E Sovia. (2015). Buat Anak Anda Jago Eksakta (Rahasia Membuka Kecerdasan Eksakta Sejak Dini). Yogyakarta: Diva Press.

Harris, B., \& Petersen, D. (2017). Developing Math Skills in Early Childhood. Issue Brief. Mathematica Policy Research, Inc., (February), 1-6. Retrieved from http://ezproxy.library.uvic.ca/login?url=http://search.ebscohost.com/login.aspx?direct=true $\& \mathrm{db}=$ eric $\& \mathrm{AN}=\mathrm{ED} 587415 \&$ site $=$ ehost-live $\&$ scope $=$ site

Kustandi. (2013). Media Pembelajaran Manual dan Digital. Jakarta: Ghalia Indonesia.

Mashar, R. (2011). Emosional Anak Usia Dini dan Strategi Pengembangannya. Jakarta: Kencana.

Mulyani, N. (2016). Dasar-dasar Pendidikan Anak Usia Dini. Yogyakarta: Kalimedia.

Newzealand, G. (2013). Number: Early Learning Progression.

Oktriyani, N. (2017). Peningkatan Kemampuan Berhitung Anak Usia Dini Melalui Permainan Lingkaran Angka Di Taman Kanak-Kanak Qatrinnada Kecamatan Koto Tangah Padang. Lectura: Jurnal Pendidikan Anak Usia Dini, 1(1), 82-96.

Rohmah, N., \& Waluyo, E. (2014). Arithmetic Dice Media as Counting Concept Introduction Media in Early Childhood Setting. Indonesian Journal of Early Childhood, 3(2), 127-133. https://doi.org/10.15294/ijeces.v3i2.9486

Rutherford, K. (2015). Why Play Math Games? US.

Smith, S. S. (2009). Early Childhood Mathematics. USA: Pearson.

Sudarna. (2014). Pendidikan Anak Usia Dini Berkarakter. Jakarta: Perpustakaan Nasional RI.

Sugiyono. (2016). MetodePenelitianPendidikan:PendekatanKuantitatif,Kualitatif, dan R\&D. Bandung: Alfabeta.

Sujiono, Y. N. (2008). Metode Pengembangan Kognitif. Jakarta: Universitas Terbuka. 
Suryana, D. (2013). Pendidikan Anak Usia Dini (teori dan praktik pembelajaran). Padang: UNP Press.

Susanto, A. (2017). Pendidikan Anak Usia Dini (Konsep dan Teori). Jakarta: Bumi Aksara.

Suyanto, S. (2003). Konsep Dasar Pendidikan Anak Usia Dini. Yogyakarta: UNY Press.

Trianto. (2011). Desain Pengembangan Pembelajaran Tematik Bagi Anak Usia Dini TK/RA \& Anak kelas awal SD/MI. Jakarta: Kencana Prenada Media Group.

Triharso, A. (2013). Permainan Kreatif dan Edukatif untuk Anak Usia Dini. Jakarta: Gaung Persada Press Group.

Ulfah., S. dan M. (2013). Konsep Dasar PAUD. Bandung: PT Remaja Rosdakarya. 